\title{
de Burgh Birch, C.B., M.D., C.M.
}

ThE son of Dr de Burgh Birch of the Madras Medical Service, de Burgh Birch was born on May I8, I852. He was educated in Switzerland, then at a school in Clifton and later at the Bristol Medical School. In I 874 he entered the University of Edinburgh, graduating M.B., C.M. in 1877 , and three years later as M.D., being awarded the gold medal. After spending three years as assistant to the professor of the Institutes of Medicine in Edinburgh, Birch was elected to the Chair of Physiology at Leeds. It was the first whole-time Chair in the School of Medicine, and a new epoch was just beginning, for the School had just been amalgamated with the Yorkshire College of Science, a constituent of the Victoria University.

Birch's first efforts were directed to building up a department worthy of his subject. There was a minimum of equipment and very little money. Nevertheless he gradually evolved simple but efficient apparatus for teaching experimental physiology and practical histology. In this he received considerable help from a local instrument-maker named Kershaw, a man of great ingenuity and technical skill. Ten years after Birch went to Leeds the present Medical School in Thoresby Place was opened. The physiology department which it contained was a tribute to his skill and inventive genius, and was probably at that time the best of its kind in the Provinces. It is perhaps not surprising that, having to devote so much of his time to teaching and the provision of adequate apparatus for it, Birch's early promise as a research worker did not materialise. On the other hand, in the invention and construction of new and improved apparatus and in the organisation of teaching he made a notable contribution to the advancement of physiology in the days when it was just becoming an experimental science.

In addition to the duties of his Chair he filled the office of Dean of the Medical School for many years with distinction. Birch retired in I9I7 on reaching the age limit and was given the title of Emeritus Professor. He was elected a Fellow of the Royal Society of Edinburgh in 1880 .

Mention must also be made of Birch's military hobby, in which his powers as an organiser were fully displayed. He raised a Medical Staff Corps which was later converted into a full unit in the Territorial Scheme. He became A.D.M.S. of this unit, but had retired when War broke out. 
On receiving an invitation to resume his command he did so, and in I9I 5 , when over sixty years of age, he accompanied it to France. For his public services he was awarded the C.B.

The years after his retirement were spent peacefully in the South of England, and he died at Bournemouth on September 18, 1937, aged eighty-five years.

H. S. R. 